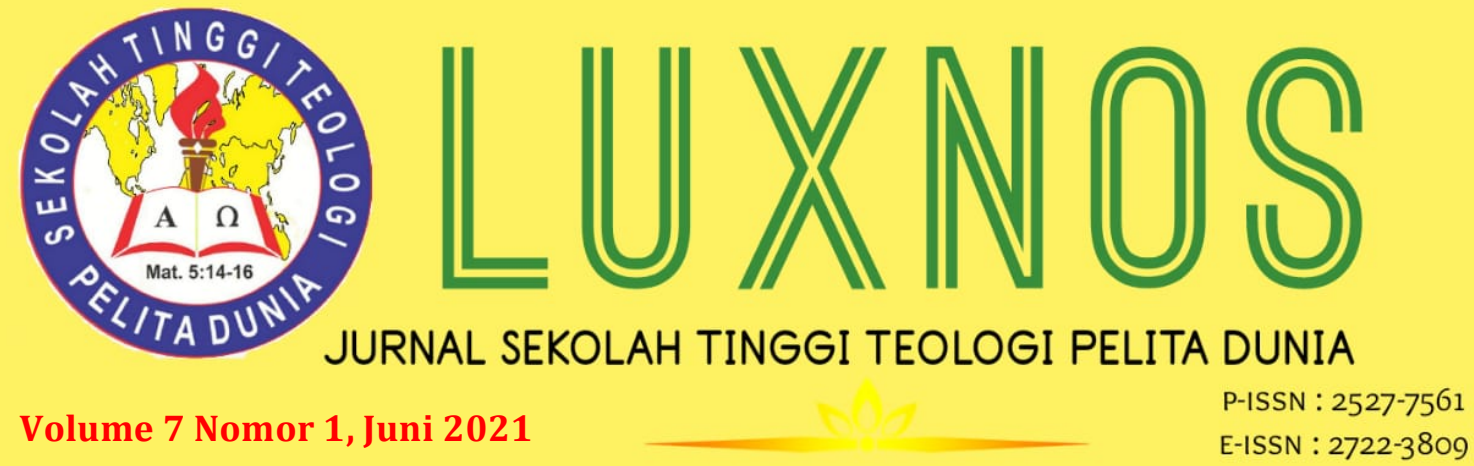

\title{
Pendidikan Agama Kristen Di Era Disrupsi: Peluang Inovasi "Blended Learning" Di Sekolah Dan Gereja
}

\author{
Dyulius Thomas Bilo \\ Sekolah Tinggi Teologi Injili Arastamar (SETIA) Jakarta \\ dyuliusthomasbilo@gmail.com
}

\begin{abstract}
This research to describe how Christian Religious Education in the Era of Disruption make use of the "Blended Learning" innovation opportunities in schools and churches. This research uses a descriptive qualitative approach that refers to efforts to describe, explain, and describe a phenomenon that occurs in the social environment. The phenomenon that we want to describe here is related to the disruption in every area of life that cannot be avoided and rejected, including in the world of religious education. Disruption by many experts is a change because off technological innovations that not only affect a person's mindset but have also had an impact on the theory and practice of human life. Disruption as a necessity that brings progress and welfare of human life. Christian Religious Education is efforts made by believers, servants of God (teachers, evangelists, pastors) and the church in the guidance of the Holy Spirit to introduce Jesus Christ and lead each individual to believe, love, and serve Jesus as Lord and his Savior. The findings of this research are that the era of disruption cannot be avoided and rejected, there have been many positive and negative effects of disruption, services off PAK learning in school and church must be disrupted if it is to survive and continue to exist as an effort to preach the gospel of Christ.
\end{abstract}

Keywords: Disruption, Innovation, Blended Learning, and Christian Religious

Education.

Abstrak: Penelitian ini bertujuan untuk memaparkan bagaimana Pendidikan Agama Kristen di Era Disrupsi memanfaatkan peluang inovasi "Blended Learning" di Sekolah dan Gereja. Penelitian ini menggunakan pendekatan kualitatif deskriptif yang merujuk pada usaha mendeskripsikan, menjelaskan, dan mengambarkan suatu fenomena yang terjadi dalam lingkungan sosial. Fenomena yang ingin dideskripsikan di sini adalah berkaitan dengan disrupsi di setiap bidang kehidupan yang tidak bisa dihindari dan ditolak termasuk dalam dunia pendidikan keagamaan. Disrupsi oleh banyak ahli disebut sebagai suatu perubahan disebabkan oleh inovasi teknologi yang tidak hanya memengaruhi mindset seseorang tetapi telah berdampak juga bagi teori dan praktik kehidupan manusia. Disrupsi sebagai suatu keniscayaan yang membawa kemajuan dan kesejahteraan kehidupan manusia. Pendidikan Agama Kristen adalah upaya yang dilakukan oleh orang percaya, hamba Tuhan (guru, penginjil, pendeta) dan gereja dalam bimbingan Roh Kudus untuk memperkenalkan Yesus Kristus dan membawa setiap individu untuk percaya, mengasihi, dan melayani Yesus sebagai 
Tuhan dan Juruselamatnya. Temuan dari penelitian ini adalah bahwa era disrupsi tidak bisa dihindari dan ditolak, telah banyak dampak positif dan negatif dari disrupsi, pelayanan pembelajaran PAK di Sekolah dan Gereja harus terdisdrupsi jika ingin bertahan dan tetap eksis sebagai suatu upaya memberitakan Injil Kristus.

Kata Kunci: Disrupsi, Inovasi, Blended Learning, dan Pendidikan Agama Kristen.

\section{Pendahuluan}

Disrupsi telah menjadi momok bagi sebagian kelompok masyarakat, namun pada saat yang sama disrupsi telah menjadi berkah bagi masyarakat lainnya. Bagi sebagian individu dan kelompok komunitas sangat berdamai dengan akibat dan dampak dari istilah ini, namun ada sebagian juga sangat benci dan tidak ingin mendengarnya.

Muara dari era disrupsi ini adalah sebenarnya adalah apa yang disebut dengan istilah era Revolusi Industri $4.0^{1}$ atau di era digitalisasi, siapapun dan kelompok masyarakat dari mana pun tidak bisa menolak dan menghindarinya. Cepat atau lambat semua orang akan berhadapan dan mengalami era disrupsi. Oleh sebab itu sangat diperlukan sikap introspeksi, restropeksi, dan evaluative sebagai tindakan preventif menghadapi hal ini. Sebagi dampak dari era disprupsi ini, maka terjadilah mobilisasi dan orkestrasi. Dunia termobilisasi dengan koneksi digital online dan terpimpin untuk bersorak, bergerak dan berkumpul dalam suatu akses dunia maya. Rhenald Kasali menuliskan, "Dengan Revolusi Industri 4.0 ketika mesin dan segala benda, baik buatan alam maupun manusia, sama-sama terhubung dengan manusia dari segala belahan dunia. Wellcome to hyperconnected society atau yang biasa disebut connected society." 2

Penjelasan lebih lanjut oleh Kasali, menyatakan bahwa, ada kecemburuan sosial sekaligus memberi apresiasi yang tinggi bagi berbagai pihak yang telah mengambil keuntungan dari era disrupsi ini, bahkan mereka telah sukses memanfaatkan teknologi secara khusus digital online ini untuk memperoleh keuntungan dari usaha tersebut. Meskipun demikian, ada juga pihak-pihak yang mengalami kegagalan dalam hal ini. Pada intinya, disrupsi menjadi sebuah kekuatan menghidupkan dan mematikan, kekuatan untuk mendapat keuntungan tetapi juga bisa merugikan dan menghancurkan segala usaha manusia. ${ }^{3}$

Dapat diketahui juga bahwa dengan adanya disrupsi, ada begitu banyak pribadi dan perusahaan menangis, menderita, dan bahkan menjadi tutup dan mati

\footnotetext{
${ }^{1}$ Lizna Novalia, A New Shape of Christian Education In Indonesian Contex: Suatu Upaya Mempersiapkan Sumber Daya Manusia yang Unggul di SETIA Jakarta, Jurnal Phronesis, vol. 2 No. 2 Desember 2019

${ }^{2}$ Rhenald Kasali, M\#O: Sebuah Dunia Baru yang Membuat Banyak Orang Gagal Paham (Jakarta: Mizan, 2019), 4

${ }^{3}$ Kasali, M\#O: Sebuah Dunia Baru, 4
} 
bisnisnya gara-gara disrupsi terutama di bidang-bidang non teknologi. Dari satu sumber mengatakan bahwa berikut ada tujuh perusahaan (bisnis) yang kandas bahkan sampai tutup atau mati karena efek disruption diantaranya dari bisnis teknologi seperti: AltaVista, Palm, AOL, Netscape, Myspace, Napster, dan Kodak. Indikasinya apabila para pebisnis yang enggan mengikuti perkembangan jaman dan berbagai turunan yang mengikutinya, dapat dipastikan ambruk dan tercerai-berai. Fakta menunjukkan bahwa semakin tinggi kemajuan teknologi, maka semakin panjang daftar perusahaan yang harus gulung tikar karena tidak sanggup lagi mendulang keuntungan atau bersaing dengan kompetitor yang uniknya seringkali berukuran lebih kecil dan modal tidak besar.4

Berdasarkan beberapa fenomena di atas, maka muncul pertanyaan bahwa, bagaimana dengan dunia pendidikan pada era disrupsi ini? Pandemi Covid 19 telah memaksa lembaga pendidikan segera berubah jika tidak mau mati. Misalnya perguruan tinggi menempuh pendidikan jarak jauh (PJJ) atau dalam jaringan (daring) suatu disrupsi yang tidak bisa dihindari dan ditolak. Masa Pandemik Virus Covid 19 ini, membuktikan lembaga perguruan tinggi baik negeri maupun swasta mana yang bisa survive. Tak bisa dihindari bahwa dampak Covid 19 membuat beberapa lembaga perguruan tinggi akhirnya menjadi kolaps dan tutup dan mungkin tidak bisa menerima mahasiswa baru dan hanya tinggal menyelesaikan studi mahasiswa yang sudah ada. Kekuatiran ini ada seperti yang dikutip dari Sindonews pada tanggal 4 Juli 2020 seorang legislator pusat yaitu Jazilul Fawaid mengatakan bahwa "Saya yakin akan banyak lembaga pendidikan tutup atau bubar atau tidak mampu menjalankan operasionalnya kembali. Bisa jadi perguruan-perguruan tinggi swasta sehabis pandemi ini tidak mampu lagi beroperasi. Ini membutuhkan turun tangan dari pemerintah, baik kebijakan anggaran, kebijakan perencanaan." 5 Hal ini memberi indikasi bahwa era disrupsi ini sangat berdampak bagi pelaksanaan pendidikan. Oleh sebab itu diperlukan suatu formula baru yang mampu memberikan terobosan baru dalam dunia pendidikan menghadapi dampak pandemic covid-19 ini.

Tidak ada lembaga pendidikan seperti akademi, sekolah tinggi, institut, dan universitas baik skala lokal, nasional dan global yang tidak terpapar disrupsi. Untuk konteks Indonesia, benar pendapat Menteri Pendidikan dan Kebudayaan, Nadiem Makarim bahwa trend global pendidikan atau pembelajaran dengan system digital study dan daring sepertinya akan bisa permanen bagi Perguruan Tinggi. Untuk menjawab persoalan dalam dunia pendidikan di era digital ini, maka perlu

\footnotetext{
${ }^{4}$ Sumber, https://www.simulasikredit.com/perusahaan-yang-mati-karena-disruptionteknologi-baru/

5 Jazilul Fawaid, sumber https://edukasi.sindonews.com/read/90540/144/banyak-lembagapendidikan-gulung-tikar-pemerintah-diminta-turun-tangan-1593871642?showpage=all, Jazilul Fawaid adalah Wakil Ketua MPR RI, dalam Talkshow Nasional Pendidikan bertajuk Dilema New Normal Merekonstruksi Sistem Pendidikan?
} 
dicanangkan trend baru dalam belajar dengan nyaman dan aman dari bahaya virus corona. Trend baru tersebut adalah blended learning. Dengan sistem blended learning ini mampu mengatasi persoalan pelaksanaan pendidikan agama Kristen dan pelayanan di Gereja dalam masa pandemic covid-19 ini.

Wakil Presiden Indonesia, Ma'aruf Amin ketika meresmikan Universitas Siber Asia yang murni melakukan pembelajaran daring, menekankan pentingnya pembelajaran daring atau e-learning dilakukan dilakukan dalam konteks Indonesia sebagai Negara kepulauan. Oleh karena dapat memudahkan masyarakat untuk mengaksesnya kapan saja dan belajar di mana saja dengan biaya yang relatif terjangkau. Selain itu waktu yang digunakan untuk belajar lebih fleksibel. Dengan demikian, masyarakat Indonesia semakin terbuka kesempatan untuk kuliah. ${ }^{6}$

Problematika dunia pendidikan di era disrupsi ini, tidak hanya berbicara tentang lembaga pendidikan tingginya, akan tetapi terkait juga dengan konten dan sistem pendidikan dan pembelajarannya. Bagaimana konten dan proses pembelajaran di era disrupsi ini? Prof. Clayton Christensen, yang merupakan penemu teori disrupsi, telah memprediksi bahwa universitas di AS pada 10-15 tahun ke depan akan bangkrut karena mayoritas universitas di sana akan mengalami disrupsi oleh berbagai jenis kuliah online seperti online learning. ${ }^{7}$

Di sini kita melihat bahwa lembaga pendidikan terutama insan pendidik (guru atau dosen) harus benar-benar membenahi konten, pendekatan terutama dalam memilih dan menggunakan metode dan media pembelajaran yang inovatif dan kreatif jika ingin bertahan dan maju dalam dunia pendidikan. Bagaimana seharusnya Pendidikan Agama Kristen (PAK) di era Disrupsi, sejauhmana era disrupsi disikapi oleh penggiat PAK baik di sekolah maupun di gereja, dan bagaimana inovasi "blended learning" PAK di Sekolah dan Gereja.

\section{Metode Penelitian}

Metode penelitian yang digunakan dalam tulisan adalah menggunakan penelitian kualitatif deskriptif. Penelitian kualitatif adalah suatu penelitian yang sifatnya deskriptif dan cenderung menggunakan analisis yang dipengaruhi oleh proses dan makna secara perspektif subjektif. ${ }^{8}$ Menurut Sugiyono penelitian deskriptif adalah penelitian dengan metode untuk menggambarkan atau menjelaskan sesuatu hasil penelitian. Penelitian deskriptif adalah penelitian yang berusaha mendeskripsikan suatu gejala, peristiwa, kejadian yang terjadi, hubungan sebab

\footnotetext{
${ }^{6}$ https://news.detik.com/berita/d-5183059/resmikan-universitas-siber-asia-wapres-marufdorong-e-learning

${ }^{7}$ https://www.yuswohady.com/2019/10/25/nadiem-dan-disrupsi-pendidikan-kita/

${ }^{8}$ Hadari Nawawi, Metode Penelitian Bidang Sosial, (Yogyakarta: Gajah Mada University Press, 1984), 78
} 
akibat, pengaruh antara variabel penelitian. Penelitian deskriptif adalah memberikan gambaran atau penjelasan, proses dan hubungan dari sejumlah variabel penelitian sosial. Tujuan metode deskriptif adalah memberikan deskripsi, penjelasan, serta validasi suatu fenomena yang diteliti baik dalam bentuk verbal maupun numerikal. ${ }^{9}$

\section{Hasil dan Pembahasan}

Sehubungan dengan penggalian pendidikan teologi terutama Pendidikan Agama Kristen (PAK) terkait dengan disrupsi hasil dan pembahasan tidak hanya pada pendahuluan yang menjadi pemantik pada pengetahuan tentang disrupsi, plus dan minusnya dampak dari disrupsi, tetapi juga mengenai isinya. Sesuai judul di atas yaitu PAK Di Era Disrupsi: Peluang Inovasi "Blended Learning" di Sekolah dan Gereja. Selanjutnya akan dibahas secara berturut-turut yaitu: Pengertian Era Disrupsi, Pengertian Pendidikan Agama Kristen, Peluang Inovasi "Blended Learning" Konteks PAK, dan Disrupsi "Blended Learning" Pendidikan Agama Kristen di Sekolah dan Gereja.

\section{Pengertian Era Disrupsi}

Era disrupsi artinya dimana dalam suatu masa atau kurun waktu tertentu terjadi perubahan drastis, perubahan besar-besaran, perubahan yang tidak bisa ditolak dan dihindari. Perubahan itu berdampak pada suatu keberadaan antara mati atau hidupnya suatu usaha atau bisnis, kekalahan atau ketangguhan suatu perusahaan atau lembaga tertentu di masa disrupsi.

Eriyanto dari suatu wibesite mengatakan istilah "disrupsi" telah dikenal puluhan tahun lalu, tetapi baru populer setelah guru besar Harvard Business School, Clayton M. Christensen, menulis buku berjudul "The Innovator Dilemma" (1997). ${ }^{10}$ Dari buku itu, Christensen menjawab pertanyaan penting, mengapa perusahaanperusahaan besar bahkan pemimpin pasar (incumbent) bisa dikalahkan oleh perusahaan yang lebih kecil, padahal perusahaan kecil tersebut kalah dalam hal dana dan sumber daya manusia. Jawabannya terletak pada perubahan besar yang dikenal dengan disrupsi. Itulah sebabnya, disrupsi bukan hanya sekadar perubahan, tetapi perubahan besar yang mengubah tatanan. Teori disrupsi banyak dipergunakan untuk menjelaskan perubahan besar, tidak semata pada dunia bisnis, tetapi juga komunikasi. Christensen sendiri tidak secara langsung mengaitkan disrupsi dengan dunia digital. Tetapi banyak ahli (seperti Paul Paetz) meyakini bahwa dunia digital mempercepat proses disrupsi. ${ }^{11}$

\footnotetext{
${ }^{9}$ Sugiyono, Metode Penelitian Kombinasi (Bandung: Alfabeta, 2011), 339-343.

${ }^{10} \mathrm{http}: / /$ journal.ui.ac.id/index.php/jkmi/article/viewFile/9945/67546121

${ }^{11} \mathrm{http}: / /$ journal.ui.ac.id/index.php/jkmi/article/viewFile/9945/67546121
} 
Kasali menegaskan bahwa disrupsi adalah suatu revolusi. Disrupsi adalah sebuah inovasi dan suatu perjalanan inovatif. Inilah inovasi yang akan menggantikan seluruh system lama dengan cara-cara baru. Disrupsi berpotensi menggantikan pemain-pemain lama dengan yang baru. Disrupsi menggantikan teknologi lama yang serba fisik dengan teknologi digital yang menghasilkan sesuatu yang benar-benar baru dan lebih efisien, juga lebih bermanfaat. ${ }^{12}$ Michael Porter mengatakan bahwa inovasi adalah kunci utama kemakmuran. ${ }^{13}$ Clayton M. Christensen mengatakan bahwa "disruptive technology should be framed as a marketing challenge, not a technological."14

Disrupsi juga berkaitan dengan perubahan mindset seseorang. Mindset adalah bagaimana manusia berpikir yang ditentukan oleh setting yang kita buat sebelum berpikir dan bertindak. Ini sama seperti ponsel yang kita setting bahasa, fitur-fitur, suara dan lain-lain sebelum kita pakai. Ada yang setting-nya kiri-kanan, ada yang central (ke tengah) dan bebas ke kiri-kanan, ada yang membuat dirinya sempit dan tengah dan diimpit batas-batas kiri-kanan yang kaku. ${ }^{15}$ Dari konsep ini bahwa seseorang akan terdisrupsi sendirinya apabila terbuka wawasannya pada dunia nyata sekelilingnya.

Dari pengertian di atas bahwa era disrupsi berbicara tentang suatu masa yaitu masa sekarang yang sedang dikuasai oleh disrupsi dimana seluruh dimensi hidup manusia mengalami disrupsi atau perubahan dan inovasi. Bagi pribadi atau perusahaan atau lembaga yang berposisi sebagai pemain lama akan tergerus sendiri oleh disrupsi terutama pelakuknya adalah digital online yang dimainkan oleh pemainpemain baru yang sangat melek IT dan dekat dunia digital online. Era disrupsi telah mengubah segala-galanya menjadi terbarukan. Persoalannya adalah apakah manusia dengan mindset-nya, budaya dan gaya hidupnya bisa berubah. Semuanya itu tergantung pada pribadi dalam memanfaatkan IT di era disrupsi.

\section{Pengertian Pendidikan Agama Kristen}

Untuk memahami PAK di era disrupsi, penulis memandang penting menyertakan pengertian PAK menurut beberapa ahli teologi dan PAK. Menurut John Piper seorang teolog mendiskripsikan PAK yaitu studi yang menganalisis kenyataan sebagai manifestasi dari kemuliaan Allah, mendiskusikannya, dan menuliskannya dengan akurat, selanjutnya mengalami keagungan Allah, diimplementasikan demi

12Rhenald Kasali, Disruption (Jakarta: PT. Gramedia Psutaka Utama, 2017), 34

${ }^{13}$ Rhenald Kasali, Tomorrow Is Today (Jakarta: Mizan, 2018), 22

${ }^{14}$ Kasali, Disruption, 149-150

${ }^{15}$ Kasali, Disruption, 305 
kebaikan manusia. Esensialnya kepada Firman atau Kalam Allah yang menghidupi orang percaya. ${ }^{16}$

E.G. Homrighausen dan I.H. Enklaar memberi penegasan tentang makna yang mendalam dari PAK dengan cara mengajarkan PAK, peserta didik dari berbagai jenjang usia dipersatukan dalam persekutuan iman yang hidup, dan dalam Dia mereka teradopsi pula ke dalam persekutuan jemaat-Nya yang percaya dan mempermuliakn Nama-Nya di segala waktu dan tempat. ${ }^{17}$

Selanjutnya Daniel Nahumara, menjelaskan arti dan tujuan tujuan akhir dari PAK dengan mengatakan bahwa itu berarti mengajak, membantu, menghantar setiap individu untuk mengenal kasih Allah dalamYesus Kristus, sehingga Roh Kudus akan memimpinnya masuk ke dalam suatu persekutuan dengan Tuhan. ${ }^{18}$

PAK adalah tindakan sadar oleh bimbingan dan dorongan Roh Kudus untuk mengajarkan pokok-pokok iman Kristen yang sesuai dengan Alkitab kepada peserta didik baik di sekolah, rumah, dan gereja dengan tujuan setiap peserta didik mengalami perjumpaan, pengenalan, dan pertumbuhan iman.

\section{Peluang Inovasi "Blended Learning” Dalam Konteks Pendidikan Agama Kristen}

Dalam bagian ini akan dibahas pengertian inovasi, pengertian "Blended Learning", dan Inovasi "Blended Learning" konteks PAK. Ketiganya akan diuraikan sebagai berikut.

\section{Pengertian Inovasi}

Everett M. Rogers menyatakan bahwa inovasi yaitu sebuah ide, gagasan, praktik ataupun objek atau benda yang disadari dan diterima yang sebagai suatu hal yang baru oleh seseorang ataupun kelompok untuk diadopsi. Selanjutnya Stephen Robbins mengungkapkan bahwa inovasi ialah sebagai suatu gagasan baru yang diterapkan untuk memprakarsai atau memperbaiki sebuah produk atau proses dan jasa. Tokoh lainnya Kuniyoshi Urabe menyatakan bahwa Inovasi bukan merupakan suatu kegiatan satu kali pukul (one time phenomenon), melainkan sebuah proses yang panjang dan kumulatif yang meliputi banyak proses pengambilan dalam keputusan di dan oleh organisasi dari mulai pada penemuan gagasan sampai implementasinya di pasar. Menurut Stephen Robbins mendefinisikan bahwa inovasi yaitu sebagai sebuah gagasan baru yang diterapkan untuk memprakarsai atau memperbarui suatu produk atau proses dan jasa. Sedangkan menurut Van de Ven, Andrew H menyatakan

\footnotetext{
16Yosia Belo, Pendidikan Agama Kristen dalam Matius 28:19-20- Jurnal Luxnos Vol. 5, No. 2, Edisi Juli-Desember 2019 2007, 26

${ }^{17}$ E.G. Homrighausen dan I.H. Enklaar, Pendidikan Agama Kristen (Jakarta: BPK Gunung Mulia, 2007), 31
} 
bahwa Inovasi ialah suatu pengembangan dan implementasi suatu gagasan-gagasan baru oleh orang yang dimana dalam jangka waktu tertentu melaksanakan sebuah transaksi-transaksi dengan orang lain dalam suatu tatanan organisasi. ${ }^{19}$

Suatu inovasi adalah penemuan baru dalam bidang apapun yang belum ada dari sebelumnya. Sebuah inovasi menghasilkan suatu ide, prinsip, praktik, objek atau hasil yang dapat dimanfaatkan manusia untuk kesejahteraannya dan membangun peradaban kehidupannya. Inovasi dapat diadopsi dan dikembangkan ke dalam halhal yang lebih detail dan dapat diaplikasikan dengan baik oleh penggunanya.

\section{Pengertian "Blended Learning"}

Terkait dengan "Blended Learning" atau pembelajaran campuran. Sejatinya belajar seharusnya menyenangkan, itulah pendapat Aristoteles abad 4 SM. Belajar adalah proses aktivitas mental seseorang dalam berinteraksi dengan lingkungannya sehingga menghasilkan perubahan perilaku yang positif baik dalam aspek pengetahuan (cognitive), sikap (affective), maupun psikomotor (psychomotor). ${ }^{20}$ Bagi Hamalik belajar merupakan proses melihat, mengamati, dan memahami sesuatu. Belajar merupakan bagian hidup manusia yang berlangsung seumur hidup dalam segala situasi dan kondisi yang dilakukan di sekolah, lingkungan keluarga, dan lingkungan masyarakat. Manusia terus belajar tanpa mengenal batas usia dengan tujuan untuk meningkatkan kecerdasaan intelektual dan peningkatan status sosialnya. ${ }^{21}$

Menurut Rusman pembelajaran merupakan sebuah sistem, yang terdiri atas berbagai komponen yang saling berhubungan satu sama yang lain. Komponen tersebut meliputi: Tujuan pembelajaran, materi/isi pembelajaran, metode pembelajaran, media dan evaluasi. ${ }^{22}$ Dari paparan Rusman di atas memberikan peluang untuk pelaksanaan sistem blended learning dengan memanfaatkan media pembelajaran agar tercapai tujuan pembelajaran itu sendiri.

Waluyo mengutip beberapa pendapat ahli dalam bukunya "Blended Learning untuk Pelatihan Vokasi" seperti Driscool \& Carliner mendefinisikan blended learning adalah mengintegrasikan atau menggabungkan program belajar dalam format yang berbeda dalam mencapai tujuan umum. Fujiawati \& Fuja S menjelaskan blended learning adalah mengacu pada pendekatan strategis dan sistematis untuk menggabungkan waktu dan metode pembelajaran, mengintegrasikan aspek terbaik dari interaksi tatap muka dan online untuk setiap disiplin ilmu, menggunakan

\footnotetext{
${ }^{19}$ Sumber, https://www.gurupendidikan.co.id/pengertian-inovasi/

${ }^{20}$ Mohammad Rusli, dkk, Multimedia Pembelajaran yang Inovatif(Yoyakarta: Andi,2017), 18

${ }^{21}$ Oemar Hamalik, Prose

s Belajar Mengajar (Jakarta:Bumi Aksara, 2004), 7

22Rusman, Model-Model Pembelajaran: Mengembangkan Profesionalisme Guru (Jakarta: Rajagrafindo Persada, 2012), 10
} 
indicator pelatihan yang tepat. Sedangkan Husamah arti blended learning sebagai hybrid learning, yang menggabungkan fitur-fitur terbaik dari sekolah tradisional dengan kelebihan dari pembelajaran online untuk memberikan instruksi yang dipersonalisasi dan berbeda di antara sekelompok pelajar. Whitelock dan Jelfs memberikan tiga defisi tentang blended learning yaitu: 1) kombinasi yang terintegrasi dari pembelajaran tradisionil dengan pembelajaran online berbasis web; 2) kombinasi dari media dan tools dalam sebuah pembelajaran e-learning; dan 3) kombinasi dari berbagai pendekatan pedagogik. Kerres dan De Witt menjelaskan blended learning adalah gabungan dari metode pembelajaran yang berbeda. Semler mendefinisiakan blended learning adalah menggabungkan aspek-aspek terbaik dari pembelajaran online kegiatan tatap muka terstruktur, dan pengalaman di tempat kerja. Sistem pembelajaran online, pelatihan di balai pelatihan (face to face), dan pengalaman di tempat kerja tentunya akan memiliki kelemahan masing-masing. Oliver dam Trigwell menguraikan blended learning adalah kombinasi teknologi berbasis web untuk mencapai tujuan pembelajaran, kombinasi dari berbagai pendekatan pedagogic, keluaran dengan atau tanpa pembelajaran teknologi, kombinasi dari pembelajaran dengan teknologi dan pembelajaran foce to face, kombinasi pembelajaran teknologi dan pemberian tugas. ${ }^{23}$

Jadi dapat diartikan blended learning atau pembelajaran campuran adalah suatu model atau metode pembelajaran yang menyatukan model satu dengan model lainnya terutama yang sifatnya konvensional atau tradisonal dengan yang modern, misalnya pembelajaran tatap muka atau face to face (offline) dengan pembelajarana jarak jauh atau PJJ (daring atau online) secara terstruktur, sistematis, berkesinambungan dan konsisten. Sistem blended learning memberikan kesempatan kepada setiap masyarakat dari berbagai daerah kota dan pelosok tanah air yang ingin belajar dan mengakses ilmu pengetahuan dengan begitu mudah dan murah pembiayannya tetapi tidak mengabaikan kualitas karena dilakukan sesuai aturan dan sistemnya.

\section{Inovasi "Blended Learning” konteks PAK}

Dari analisis penulis bahwa peluang inovasi pembelajaran campuran konteks PAK dapat dilihat dari dua hal utama yakni konten PAK, dan bagaimana penyalurannya dari sisi metodenya. Mengenai isi atau konten dari PAK, mengandung pengertian bahwa, sejak semula hingga kini, bahkan masa yang akan datang, isi atau konten dari pada PAK adalah Alkitab beserta dengan rumusan doktrin atau teologi yang telah diterima secara umum. Salah satu semboyan Reformasi "Sola Scriptura" keyakinan bahwa "Hanya Alkitab Firman Allah" adalah harus kuat dalam benak

${ }^{23}$ Sri Teguh Waluyo, Blended Learning untuk Pelatihan Vokasi (Bandung: PT. Srikandi Empat Widya Utama, 2020), 112-113. 
pendidik PAK. Firman Allah yang terdapat dalam 66 kitab yang dikanonisasi yakni dari kitab Kejadian sampai Wahyu adalah tetap untuk selama-lamanya. Betapa pun hebat serangan terhadap Alkitab, tetap tidak berubah dan final adalah Firman Tuhan. Bagi orang-orang percaya secara khusus para hamba Tuhan selaku pendidik (guru dan dosen) mesti benar-benar yakin pada doktrin utama tentang Alkitab bahwa Alkitab ada firman Allah yang diilhamkan oleh Roh Kudus (inspirasi) dan tanpa salah dalam bahasa aslinya atau autographanya (inneransi). Tetapi tentunya diakui bahwa dalam proses transliterasinya (penterjemahan) ke berbagai bahasa di dunia mengalami kesulitan sehingga tidak bisa menghindari keterbatasan dan bahkan mungkin ada kesalahan. Tetapi kita bersyukur dan yakin bahwa ada penulis agung yaitu Roh Kudus dan firman yang menjadi daging (manusia) yaitu Yesus Kristus akan menjaga dan merawat firman-Nya dalam Alkitab sehingga tetap lestari dan relevan di setiap zaman dan bahasa.

Sehubungan metode penyaluran PAK dapat dijelaskan bahwa dalam dunia pendidikan dan pembelajaran; untuk mencapai tujuan pengajaran yang telah ditetapkan diperlukan teknik, cara, atau sistem yaitu metode. Menurut B.S. Sidjabat, metode sama dengan cara atau prosedur. Secara etimologi, metode berasal dari istilah meta artinya "sesudah" dan hodos artinya "cara, jalan". ${ }^{24}$ Sedangkan menurut Eli Tanya, metode adalah "bagaimananya" dari suatu pokok ajaran, artinya bagaimana mengajarkannya, sedangkan pokok ajaran adalah "apanya" yang akan diinformasikan. ${ }^{25}$

Randolph Crum Miller mengutip pandangan Jhon Dewey mengungkapkan bahwa metode berarti pengaturan pokok pelajaran yang menjadikan paling efektif dalam pemakaiannya. ${ }^{26}$ Sedangkan Iris V. Cully mengatakan bahwa hal "apa" itu menentukan syarat-syarat bagi "bagaimana"27 Harianto GP mengatakan bahwa metode dapat diartikan sebagai "teknik", "cara", atau "prosedur". Dalam setiap kegiatan pembelajaran diperlukan metode yang tepat dan relevan untuk mencapai tujuan. Oleh karena itu, dalam persiapan mengajar dengan target menghasilkan rencana pengajaran, pendidik harus memikirkan metode pengajaran secara saksama. Untuk menentukan metode pengajaran yang tepat, pendidik harus memikirkan halhal yang mempengaruhi proses pembelajaran, karakteristik peserta didik yang dihadapi, tujuan pembelajaran serta cara mencapai tujuan yang telah ditetapkan. ${ }^{28}$

\footnotetext{
1999), 37.

${ }^{26}$ Randolph Crump Miller, Education For Christian Living (Engelwood Cliffs Prentice Hall, 1990), 159.

${ }^{27}$ Iris V. Cully, Dinamika Pendidikan Agama Kristen (Jakarta: BPK Gunung Mulia,1976), 113.

${ }^{28}$ Harianto GP, Pendidikan Agama Kristen Dalam Alkitab dan Dunia Pendidikan Masa Kini (Yogyakarta: yayasan Andi, 2012), 17-18
}

${ }^{24}$ Samuel Sidjabat, Mengajar Secara Profesional (Bandung: Kalam Hidup,2009), 229.

25Eli Tanya, Gereja dan Pendidikan Agama Kristen (Cipanas: Sekolah Tinggi Theologi Cipanas, 
Penggunaan metode mengajar dalam pendidikan di sekolah Kristen dan gereja, sangat penting tetapi sangat perlu bijaksana memilih dan menggunakan metode yang tepat agar dapat menolong sesama atau jemaat dalam mengerti kebenaran Allah. Bagi Randolph Crum Miller metode PAK begitu diperlukan untuk menuntaskan isi pembelajaran agar menjadi efektif dan efisien bagi kebutuhan peserta didik. ${ }^{29}$

Lois E. Lebar menjelaskan bahwa Mengajar Alkitab adalah sebuah metode pendidikan. Alkitab itu penting, tetapi sebagai sarana dan bukan tujuan. Hanya mengajar Alkitab bukanlah sasaran yang sesungguhnya. Kita haruslah mengajar Alkitab sedemikian sehingga ia akan menolong murid untuk memahami kebenaran Firman Allah dan dengan taat menerapkan kebenaran itu dalam kehidupan. Ada suatu kesenjangan yang besar antara ukuran-ukuran kedewasaan Allah dan tingkat di mana kita ada sekarang ini. Kesenjangan ini haruslah digali bersama dengan orangorang Kristen yang dikaruniai secara rohani. Inilah inti dari metode-metode belajar yang baik. ${ }^{30}$

Bagaimana sikap Tuhan Yesus sebagai Guru Agung terhadap hal pengajaran (pendidikan) dan komponen-komponen pembelajaran lainnya seperti metode mengajar? Apakah Yesus juga memiliki sikap positif terhadap pemilihan dan penggunaan metode dalam pembelajaran-Nya? Apakah Yesus menggunakan metode dan relevan bagi pengajaran-Nya?

Pertanyaan tersebut di atas dapat terjawab ketika menyelidiki Alkitab, khususnya yang berkisah tentang Yesus. Metode mengajar sangat penting bagi diriNya dalam proses pembelajaran karena sangat berkaitan erat dengan kegiatan pembelajaran. Metode merupakan bagian penting dari proses pembelajaran dan apabila metode yang dipilih sangat efektif akan menunjang tercapainya tujuan-tujuan yang telah ditentukan dan disiapkan sebelumnya oleh guru atau dosen. Dien Sumiyatiningsih memuji penggunaan metode dalam pengajaran Yesus, ia menyatakan "Tuhan Yesus dengan sadar menggunakan bermacam-macam metode sesuai dengan tujuan, keadaan peserta didik, bahan, dan keadaan lingkungan. Dia menggunakan metode yang menarik dengan cara mengaktifkan orang untuk belajar melalui perbuatan dan partisipasi." 31

J.M. Price juga dalam tulisannya mengungkapkan kekagumannya terhadap keahlian Yesus Guru Agung menggunakan metode mengajar yang tepat dan relevan dengan materi pengajaran dan situasi pendengarnya pada waktu itu. Demikian tulisannya: "Apakah Yesus secara sengaja mempelajari dan memakai metode-metode dalam pengajaran-Nya tidaklah dapat dipastikan. Mungkin tidak, teristimewah jikalau

${ }^{29}$ Miller, Education For Christian Living, 242.

${ }^{30}$ Lois E. Lebar, Education That Is Christian (Malang: Gandum Mas, 2009), 200-201.

31Dien Sumiyatiningsih, Mengajar dengan Kreatif dan Menarik (Yogyakarta: Andi, 2006), 48. 
hal itu kita maksudkan mempelajari dan memakai metode-metode seperti kita. Tetapi nyatalah Ia ahli sekali dalam hal memakai metode-metode dalam pekerjaan-Nya. Metode-metode itu merupakan hal yang biasa bagi-Nya, dan tumbuh dari keadaan dan kebutuhan, bukan hal yang sengaja dipelajari dan direncanakan. Dalam pemakaian metode-metode Ia tiada taranya. Tak pernah ada orang yang mengajar seperti Dia."32

Dalam mengajar, Yesus kaya dengan metode-metode mengajar yang patut dipelajari dan praktikkan oleh para guru dan dosen saat ini. Dimana metode-metode mengajar Yesus telah telah memberi kesan yang mempesona bagi para pendengar pada waktu itu dan menginspirasi banyak guru dan dosen saat ini untuk mendalami, mengembangkan, dan mempraktikannya sesuai dengan konteks pendidikan pada zaman-Nya.

\section{Disrupsi “Blended Learning” Pendidikan Agama Kristen di Sekolah dan Gereja}

Menjawab pergumulan bagaimana peluang inovasi pembelajaran campuran konteks PAK kekinian di sekolah dan Gereja era disrupsi, akan dipaparkan tentang: Allah adalah sang disruptif utama, mendisrupsi diri sendiri penting, Pendidikan Agama Kristen di Sekolah dan Gereja harus terdisrupsi, multi dimensi terdisrupsi, mixed: Hermeneutika dan Homiletika, analisis teks-konteks dan aplikasi-relevansi, ibadah dan pelayanan harus terdisrupsi, dan pelayanan pembelajaran PAK di Sekolah dan Gereja terdisrupsi.

\section{Allah adalah Sang Disruptif Utama}

Allah adalah pencipta teknologi. Secara teologis, teknologi merupakan buah pikiran, bibir (perkataan, sabda dan firman), dan perbuatan Allah. Melihat Kejadian 1 nampak bahwa istilah menciptakan atau bara dalam bahasa Ibrani yaitu menciptakan atau mengadakan sesuatu yang belum ada sebelumnya dan pada awal penciptaan dunia istilah bara itu hanya ada dalam pikiran Allah dan diwujudkan sendiri melalui firman dan perbuatan-Nya.

Istilah ini merupakan dasar dan benang merah munculnya teknologi hingga sekarang. Teknologi yang sekarang kita kenal tidak hanya secara fisik tetapi juga melalui dunia maya adalah kreasi manusia dari apa yang diciptakan Allah sebelumnya. Bisa dikatakan bahwa Allah menciptakan bahan bakunya, manusia dengan mewarisi gambar dan rupa Allah menemukan, mengembangkan, dan menghasilkan hal-hal baru dari apa yang sebelumnya Allah sudah ciptakan dan sediakan. Secara alkitabiah tidak ada yang baru di dunia ini, demikian juga dikatakan dalam Pengkhotbah 1:9.

32J. M. Price, Jesus The Teacher di-Indonesiakan Yesus Guru Agung (Bandung: Lembaga Literatur Baptis, 1997), 99. 
Sesungguhnya semuanya berasal dari Allah tidak ada yang baru bagi Allah. Dan bagi manusia sesungguhnya yang ada adalah penemuan dan pemanfaatnya bagi kemuliaan Tuhan dan kesejahteraan manusia. Itulah sebabnya setiap Allah menyelesaikan proses penciptaan dunia ini, Allah berkata, "sungguh amat baik" $(b d k$. Kej. 1:4, 12, 18, 25, 31). Penulis Kitab Ratapan yaitu Yeremia memahami benar Allah sebagai pribadi yang dinamis, terbuka dan bahkan menciptakan perubahan dan pembaharuan, ia mengakui teknologi Allah setiap hari seperti yang termaktub dalam Ratapan 3:22-26.

\section{Mendisrupsi diri sendiri penting}

Dalam Mazmur 26:2 mengeaskan bahwa pemazmur terbuka pada Allah untuk dievaluasi dan dikoreksi agar mengalami pembaharuan dan perubahan terutama secara rohani, iman, dan moral.

Ketika banyak perusahaan mengalami kehancuran usaha karena tidak siap dan tidak mau berubah dan segera mencari solusi, salah satu pemimpin atau Wakil Presiden Komisaris PT. Adaro Energy Tbk, Garibaldi "Boy" Tohir solusi dari kehancuran karena disrupsi adalah kuncinya ada pada kemauan mendisrupsi diri sendiri, baginya sebelum terdisrupsi lebih baik memilih mendisrupsi diri sendiri lebih dulu. ${ }^{33}$ Self disruption adalah mengubah atau merubah diri sendiri. Disrupsi adalah perubahan, change! Tetapi bukan sekedar berubah. Perubahan benar terjadi ketika hadirnya masa depan ke masa kini, maka tepatlah today becomes yesterday, tomorrow becomes today, tomorrow is today. Dan hadirnya masa depan itu adalah terutama karena peran teknologi. ${ }^{34}$

Memperkuat pemahaman diri untuk terus melakukan self disruption untuk mempersiapkan masa depan baru, Tumiyana, CO PT.PP menyampaikan bahwa kita masuk ke dalam sebuah lingkungan baru yang berubah dengan cepat. Kita tidak cukup hanya mendatangkan teknologi baru, tetapi juga perlu mempersiapkan SDM dan kemampuan pembiayaannya. Ini adalah sebuah kesempatan besar yang tak pernah datang sebelumnya. ${ }^{35}$

Jadi hal ini dapat disederhanakan dari istilah self disruption bahwa tanpa instropeksi, restropeksi dan evaluasi diri seseorang, lembaga perusahaan, pendidikan, kesehatan, dan lain sebagainya atas kelemahan dan kekurangan ini, maka perubahan (disrupsi) itu akan menimpah dan mematikan.

${ }^{33}$ Rhenald Kasali, Self Disruption (Jakarta: Mizan, 2018), 32

${ }^{34}$ Kasali, Self Disruption, 111-112

${ }^{35}$ Rhenald Kasali, Tomorrow is Today (Jakarta: Mizan, 2018), 25 


\section{Pendidikan Agama Kristen di Sekolah dan Gereja Harus Terdisrupsi}

Pendidikan di Indonesia sebagaimana diungkapkan oleh Kasali dalam keprihatinannya bahwa, "sudah lama saya gelisah dengan metode pembelajaran di sekolah-sekolah yang terlalu mengutamakan keunggulan kognitif, dimana guru-guru merasa hebat kalau peserta didiknya bisa mencapai nilai rata-rata di atas 80 , dengan mengabaikan peserta didik aktif, namun tidak berprestasi baik secara akademis."36 Pandangan ini tentu memerlukan kebijaksanaan dalam mencermatinya sebab inti dari pembelajaran adalah berpusat pada peserta didik dan bukan pada guru semata. Artinya bahwa metode pembelajaran yang efektif adalah menjadikan peseta didik sebagai pembelajar bukan sebagai pelajar yang hanya menerima ilmu dari guru (transfer knowledge). Metode ini sudah lama ditinggalkan dengan adanya program siswa belajar aktif. Dengan demikian setiap peserta didik akan menjadikan pengetahuan tersebut sebagai sesuatu yang penting dari kehidupannya.

Di sini bukan hanya soal metode yang relevan dalam mengajar tetapi yang paling penting juga adalah gurunya. Pendidikan yang terdisrupsi dimulai dari insaninsan pelaku pendidikan dan pembelajaran. Gurulah insan pembawa perubahan (disrupsi) itu. Jawaban ini tepat bahwa guru harus memang berbenah tanpa perlu terlalu terbelenggu oleh birokrasi dan sistem. Guru memang harus melakukan perubahan. Guru harus mengubah pola menerangkan dengan lebih banyak berdiskusi.

Menghadapi kenyataan disrupsi ini, maka pembelajaran pun beralih untuk menggunakan teknologi. Tetapi tidak sekedar menggunakan LCD dan PowerPoint, bukan pula peserta didik hanya sebatas mengumpulkan tugas via e-mail. Perubahan ini lebih bersifat ekstrim yang membutuhkan profesionalitas guru dalam melakukan perpaduan berbagai teori (mixed theory) dalam mengejawantahkan materi pengajarannya. Jadi, peserta didik tidak hanya mendapatkan pengetahuan, tetapi juga pengalaman yang singkron dengan kehidupan nyata. ${ }^{37}$ Salah satu metode yang dapat dilakukan dalam pembelajaran yang efektif maka sistem blended learning jawabannya. Meskipun dalam masa pendemik Covid-19, proses pendidikan mesti tetap berjalan sebagaimana mestinya. Dengan sistem blended learning akan meberi ruang banyak bagi peserta didik dan guru untuk mengekspresikan diri dalam pembelajaran.

Para pendidik PAK yang merupakan wakil Tuhan di setiap ruang-ruang belajar pun demikian, janganlah cepat puas dengan pencapaian kognitif peserta didik, guru haruslah mampu menilai dan menyentuh aspek afektif dan psikomotorik peserta didik untuk mempersiapkan diri mereka memasuki lingkungan masyarakat, dunia

${ }^{36}$ Rhenald Kasali, Self Driving: Menjadi Driver atau Pasengger? (Bandung:Mizan Media Utama, 2016), 50

${ }^{37}$ Grafura dan Wijayanti, Spirit Pedagogi di Era Disrupsi, 32 
kerja, dunia pelayanan. Maka seyogianya pendidik dalam pengajaran hendaknya mampu menjembatani dunia teori dengan dunia nyata agar kelak peserta didik dapat beradaptasi dan bekerja serta melayani dengan baik.

\section{Multi dimensi terdisrupsi}

Pembelajaran campuran atau blended learning memberi dampak pada semua lini kehidupan. Artinya tidak ada aspek atau bidang-bidang tertentu yang tidak mengalami disrupsi. Semuanya harus terdisrupsi, maka multi disrupsi begitu penting. Secara jasmani seperti teknologi, pendidikan, kesehatan, ekonomi, memang haruslah mengalami disrupsi. Tetapi sangat penting aspek moral, iman, rohani harus juga terdisrupsi. Paulus menegaskan dalam suratnya kepada jemaat di Roma bahwa "janganlah kamu menjadi serupa dengan dunia ini, tetapi berubahlah oleh pembaharuan budimu, sehingga kamu dapat membedakan manakah kehendak Allah dan yang sempurna." (Rm.12:2), lebih tegas lagi Paulus menuliskan, "Janganlah kamu kalah terhadap kejahatan, tetapi kalahkanlah kejahatan dengan kebaikan." (Rm. 12:21).

Semua dimensi hidup manusia yaitu rohani dan jasmani harus terdisrupsi. Dalam Kolose 3:5-10 demikian bunyinya "Karena itu matikanlah dalam dirimu segala sesuatu yang duniawi, yaitu percabulan, kenajisan, hawa nafsu, nafsu jahat dan juga keserakahan, yang sama dengan penyembahan berhala, semuanya itu mendatangkan murka Allah (atas orang-orang durhaka). Dahulu kamu juga melakukan hal-hal itu ketika kamu hidup di dalamnya. Tetapi sekarang, buanglah semuanya ini, yaitu marah, geram, kejahatan, fitnah, dan kata-kata kotor yang keluar dari mulutmu. Jangan lagi kamu saling mendustai, karena kamu telah menanggalkan manusia lama serta kelakuannya, dan telah mengenakan manusia baru yang terusmenerus diperbaharui untuk memperoleh pengetahuan yang benar menurut gambar khaliknya."

Manusia baru yang dimaksudkan adalah manusia rohani yang hidup dalam buah Roh, dalam Galatia 5:22-23,25, Rasul Paulus menegaskan "Tetapi buah Roh ialah: kasih, sukacita, damai sejahtera, kesabaran, kemurahan, kebaikan, kesetiaan, kelembalembutan, dan penguasaan diri. Tidak ada hukum yang menentang hal-hal itu. Jika kita hidup oleh Roh, baiklah kita berjalan sesuai dengan Roh. Jikalau kita hidup oleh sebab Roh itu, biarlah juga kita berjalan menurut Roh itu. Roh Allah sudah memberikan kepada kita hidup yang baru; oleh sebab itu Ia jugalah harus menguasai hidup kita."

\section{Mixed: Hermeneutika dan Homiletika, analisi teks- konteks dan aplikasi-relevansi}

Pembelajaran campuran (mixed learning) dalam pesan dan realisasi PAK harus mampu menjembatani antara teks dan konteks serta relevansinya. Sejak dari 
kekekalan sampai kekekalan firman Tuhan tidak berubah tidak boleh ditambah dan dikurangi. Dalam Wahyu 22:18 “Aku bersaksi kepada setiap orang yang mendengar perkataan-perkataan nubuat dari kitab ini: "Jika seorang menambahkan sesuatu kepada perkataan-perkataan ini, maka Allah akan menambahkan kepadanya malapetaka-malapetaka yang tertulis di dalam kitab ini.Dan jikalau seorang mengurangkan sesuatu dari perkataan-perkataan dari kitab nubuat ini, maka Allah akan mengambil bagiannya dari pohon kehidupan dan dari kota kudus, seperti yang tertulis di dalam kitab ini." Ada konsekuensi bagi yang melakukannya. ${ }^{38}$

Tugas para hamba Tuhan (pendidik, pendeta, penginjil, teolog, dan gembala) adalah harus mampu menggali teks firman Tuhan sesuai bahasa aslinya dengan baik, memperhatikan konteksnya, lalu ia harus mampu menafsirnya. Tidak berhenti sampai di situ, tugas selanjutnya adalah harus mampu mengkhotbahkan dan menguraikannya dengan baik kepada jemaat atau murid-muridnya. Dalam menguraikan atau mengkhotbahkan firman Tuhan para pelayan harus mampu mencari dan menjelaskan aplikasi dan relevansinya dalam kehidupan jemaat dan murid-muridnya. Maka akan terjadi mix yaitu pendalaman teks dan konteks melalui Hermeneutika dan Homiletika dan analisis teks, konteks, dan aplikasi-relevansinya. Itulah harta bejana yang indah bagi kehidupan iman dan rohani domba-domba Allah.

\section{Ibadah dan pelayanan terdisrupsi}

PAK di era disrupsi membawa dampak bagi ibadah dan pelayanan. Mungkin semua pemimpin sinode, gembala jemaat, para majelis dan anggota jemaat tidak menduga bahwa ibadah yang sifatnya konvensional berkumpul bersama dan ramairamai ke gedung gereja, dan terpesona atau terinspirasi oleh figure gembala atau pendeta. Takkala Virus Covid 19 dan mutasinya menghantam Indonesia, mau tak mau protokol kesehatan harus dijalankan; memakai masker, sanitizer, mencuci tangan, menjaga jarak, dan menghindari kerumunan. Ibadah mulai dibatasi ke gereja dan lebih banyak dilakukan di rumah. Kalaupun diizinkan hanya bisa 25-50\% anggota jemaat boleh hadir.

Perubahan segera dan sudah terjadi. Organisasi gereja bersama pemimpin sinode, gembala dan anggota majelis harus segera memutuskan format baru bergereja, kalau tidak lama kelamaan anggota jemaat akan terbiasa dan terpengaruh dengan gaya, isi dan metode khotbah dari pengkhotbah melalui digital online, sudah bisa diperkirakan bahwa sebagian atau mungkin sudah banyak anggota jemaat telah terpesona, terpengaruh dan bahkan sudah pindah organisasi karena layanan yang baik dari pelayan firman Tuhan digital online. Ini memang menyedihkan dan tidak

38 Jarwati Saputra, Dewi Priskawati, Blended Learning: Solusi Pembelajaran New Normal Untuk Pendidikan Agama Kristen Di Era Revolusi Industri 4.0 dalam Jurnal Didaxei, Vol. 1 No. 22020 
bisa diharapkan terjadi. Tapi itulah disrupsi. Tetapi bukanlah disrupsi kalau hanya membawa banyak dampak negatifnya, sungguh disrupsi itu, juga menjanjikan dan membawa dampak positif yang terlalu banyak dibanding hal negatifnya. Ada kabar gembira bahwa justru dengan keadaan seperti ini peran teknologi dalam ibadah dan pelayanan urgent menjadi pilihan utama dalam setiap keputusan rapat gereja. Disrupsi teknologi dan pengaruh virus Covid 19 justru membuka pikiran terbuka bagi peningkatan dan pengemasan layanan ibadah dan pelayanan gerejawi.

Justru dengan disrupsi bisa terjadi penghematan waktu dan biaya, hamba Tuhan yang melayani dan jemaat yang ikut ibadah tidak harus ke gereja cukup berada di tempat yang kuat signal internet dan cukup paket internetnya. Pelayanan ibadah yang terlalu lama dan liturgi yang padat dan membosankan bisa disederhanakan sehingga tidak terlalu lama ibadahnya. Firman Tuhan disampaikan lebih sampai pesan isinya karena tidak terlalu banyak dibumbui dengan hal-hal yang tidak penting dan tidak ada hubungannya dengan teks firman Tuhan. Jemaat pun tidak terlalu berat membagi waktu dan buru-buru ke gereja karena ia bisa mengaksesnya di rumah atau di tempat mana ia berada. Dalam banyak cerita membangun dari beberapa gembala atau pendeta justru saat ditetapkan ibadah dari rumah, persembahan bukannya menurun atau sedikit justru mengalami peningkatan. 39

Dengan media sosial seperti WhatsApp, Youtube, Facebook, Zoom, google meet, Microsoft 365 atau teams, para majelis terutama gembala atau pendeta dapat memanfaatkan medsos untuk efektif pelayanan. Para gembala atau pendeta akan mudah terhubung, menyapa, dan berkomunikasi serta mendeteksi keberadaan jemaat dengan statusanya. Ibadah-ibadah dengan live streaming dengan mudah dilakukan. Ayat-ayat firman Tuhan dan renungannya dapat dengan mudah dikirim dengan media seperti WA dan medsos lainnya. Khotbah-khotbah harian atau minggu para gembala atau pendeta akan mudah sampai ke jemaat karena mereka bisa mengaksesnya. Yang terpenting di sini adalah komunikasi, koordinasi, kesinambungan, konsistensi pelayanan serta ketersediaan sarana IT dan operatornya.

Kelompok-kelompok belajar firman Tuhan seperti kelompok sel, pemuridan bisa dengan mudah dilakukan secara daring seperti layaknya pembelajaran pada umumnya. Dengan membuat Grup di media sosial seperti WhatsApp, Telegram, atau platform lain dalam rangka belajar akan mudah diikuti. Grafura dan Wijayanti mengatakan bahwa di era digital, pembelajaran tak lagi dibatasi oleh ruang dan tanda bel masuk dan pulang. Pembelajaran masa kini jauh melampaui itu. Pembelajaran bukan lagi 2x45 menit dalam seminggu per satu mata pelajaran, tetapi bisa dilakukan selama 24 jam, setiap saat, dan tanpa jeda. Manfaatnya sungguh luar biasa, yakni: 1)

39 Jarwati Saputra, Dewi Priskawati, Blended Learning: Solusi Pembelajaran New Normal Untuk Pendidikan Agama Kristen Di Era Revolusi Industri 4.0 dalam Jurnal Didaxei, Vol. 1 No. 22020 
Pembelajaran menjadi sangat menarik, kreatif, serta interaktif. 2) Pembelajaran tidak lagi monoton, bahkan boleh jadi guru yang satu-satunya dapat menerapkan teknikteknik terbaik di sekolah.3) Peserta didik akan menjadi sangat antusias. 4) guru tidak perlu repot terlalu banyak bicara. Dengan sekali klik, ssemua bisa melakukan interaksi. 5) Di dalam group tentu ada jejak yang masih bisa dibaca ulang. Peserta didik di kelas lain bisa ikut membacanya saat mereka luang. ${ }^{40}$

\section{Pelayanan Pembelajaran PAK di Sekolah dan Gereja terdisrupsi}

Pembelajaran PAK yang diselenggarakan di sekolah dan Gereja harus segera terdisrupsi. Blended learning mesti nampak dalam pembelajaran-pembelajaran PAK di sekolah dan gereja yang menguji perpaduan yang tak terelakkan yaitu penyiapan materi pembelajaran, pelaksanaan pembelajaran, penentuan dan pemanfaatan metode dan media pembelajaran, dan evaluasi pembelajaran. Bukan hanya itu, blended learning juga telah mendorong para pendidik menyeimbangkan materi dan pendekatannya dari sisi taksonomi Bloom yakni penguatan kognif, afektif dan psikomotorik secara seimbang dan merata dalam setiap pembelajaran. ${ }^{41}$

Pembelajaran dengan memaksimalkan blended learning, tidak hanya terjadi di sekolah atau lembaga pendidikan tetapi juga terjadi di gereja. Era disrupsi ditambah lagi dengan masifnya penyebaran Covid 19 memaksa gereja memilih dan menerapkan pelayanan berbasis virtual dan digital. Liturgi ibadah yang begitu apik dan panjang, pujian dan penyembahan serta khotbah-khotbah yang panjang segera berhenti dan beralih ke pelayanan ibadah yang digital dan efisien waktunya.

Pelayanan dan pembelajaran di sekolah-sekolah minggu pun mungkin juga termasuk pemuda dan orang dewasa segera berubah menjadi pelayanan dan pembelajaran yang begitu berbobot dan kreatif, menarik dan empatik karena sedemikian dipersiapkan dengan baik tidak hanya isi khotbah dan pelayanan melainkan efektifitas dari sisi pujian, penyembahan, pengumuman dan infrastruktur digital yang begitu baik menghantar pelayanan para mejelis begit baik sampai kepada jemaat-jemaat di rumah.

Tidak ada kata lain selain berubah paradigmanya, berubah cara belajar dan cara pelayanannya, berubah dan efisien isi khotbah atau pengajaran, dan begitu kreatif tampilan platform pelayanan yang bisa menjawab kebutuhan peserta didik dan umat di masa era disrupsi. ${ }^{42}$

\footnotetext{
${ }^{40}$ Grafura dan Wijayanti, Spirit Pedagogi di Era Disrupsi, 90

41 Jarwati Saputra, Dewi Priskawati, Blended Learning: Solusi Pembelajaran New Normal Untuk Pendidikan Agama Kristen Di Era Revolusi Industri 4.0 dalam Jurnal Didaxei, Vol. 1 No. 22020

42 Jarwati Saputra, Dewi Priskawati, Blended Learning: Solusi Pembelajaran New Normal Untuk Pendidikan Agama Kristen Di Era Revolusi Industri 4.0 dalam Jurnal Didaxei, Vol. 1 No. 22020
} 


\section{Kesimpulan}

PAK di era Disrupsi mengetangahkan secara terbuka perubahan-perubahan yang disadari atau tidak disadari segera oleh guru PAK, dosen teologi, hamba Tuhan, dan gereja harus segera sikapi. Era disrupsi telah berhasil menyadarkan bagi yang mau belajar dan segera berubah bukan hanya itu dampak era disrupsi juga berhasil mempermalukan dan bahkan mematikan mereka-mereka yang tidak mau berubah, yang merasa dalam status quo, yang merasa hebat dan mengandalkan keberhasilannya di masa lalu tetapi ketika apa yang dikerjakan dan dihasilkan itu tidak bertahan menghadapi perubahan yang terjadi, barulah mereka sadar. Era disrupsi menolong mereka-mereka yang berani berubah dengan berhasil memilih pilihan-pilihan alternative dari perubahan tersebut.

PAK tidak hanya berhenti di ruang-ruang kelas pembelajaran, PAK tidak hanya berhenti di ruang-ruang ibadah, ruang-ruang pembinaan, di bangku-bangku kuliah teologi, dan di gereja. Era disrupsi telah memengaruhi stakeholders, pengambil kebijakan, pimpinan lembaga pendidikan keagamaan, sinode-sinode, gereja-gereja lokal, dan para pendidikan untuk segera mengambil langkah-langkah strategis demi perubahan pembelajaran yang lebih humanis dan rohaniah. Sistem dan strategi pembelajaran yang berbasis human centre yang lebih dominan pada teknis-teknis pembelajaran monoton dan kaku telah berubah dan harus terbiasa dengan system belajar digital, virtual, dan online. Beragam metode belajar yang dapat dipilih dan diakumulasikan satu dengan yang lain dapat menjadi pilihan pembelajaran yang asyik namun memiliki bobot yang sangat baik. Blended learning yang memadukan pembelajaran konvensional dan modern tentu pilihan yang tepat baik untuk pembelajaran di bangku-bangku studi maupun dalam pelayanan pendidikan di Gereja.

\section{Referensi}

Cully, Iris V., Dinamika Pendidikan Agama Kristen. Jakarta: BPK Gunung Mulia,1976. GP, Harianto, Pendidikan Agama Kristen Dalam Alkitab dan Dunia Pendidikan Masa Kini. Yogyakarta: yayasan Andi, 2012.

Grafura Lubis dan Ari Wijayanti, Spirit Pedagogi di Era Disrupsi. Yogyakarta: Laksana, 2019.

Hamalik Oemar, Proses Belajar Mengajar. Jakarta: Bumi Aksara, 2004.

Homrighausen. E.G. dan I.H. Enklaar, Pendidikan Agama Kristen. Jakarta: BPK Gunung Mulia, 2007.

Kasali, Rhenald, Disruption. Jakarta: PT. Gramedia Psutaka Utama, 2017.

-------, M\#O: Sebuah Dunia Baru yang Membuat Banyak Orang Gagal Paham (Jakarta: Mizan, 2019. 
--------, Rhenald, Self Disruption. Jakarta: Mizan, 2018.

-------, Rhenald, Self Driving: Menjadi Driver atau Pasengger? Bandung: Mizan Media Utama, 2016.

-------, Rhenald, Tomorrow Is Today. Jakarta: Mizan, 2018.

Lebar, Lois E., Education That Is Christian. Malang: Gandum Mas, 2009.

Miller, Randolph Crump, Education For Christian Living. Engelwood Cliffs Prentice Hall, 1990.

Nahumara, Daniel, Pembimbing Pendidikan Agama Kristen. Bandung: Jurnal Info Media, 2007.

Price J. M., Jesus The Teacher di-Indonesiakan Yesus Guru Agung. Bandung: Lembaga Literatur Baptis, 1997.

Rusli, Mohammad, dkk, Multimedia Pembelajaran yang Inovatif. Yoyakarta: Andi,2017. Rusman, Model-Model Pembelajaran: Mengembangkan Profesionalisme Guru. Jakarta: Rajagrafindo Persada, 2012.

Sidjabat, Samuel, Mengajar Secara Profesional. Bandung: Kalam Hidup,2009.

Sumiyatiningsih, Dien, Mengajar dengan Kreatif dan Menarik. Yogyakarta: Andi, 2006. Tanya, Eli, Gereja dan Pendidikan Agama Kristen. Cipanas: Sekolah Tinggi Theologi Cipanas, 1999.

Waluyo, Sri Teguh, Blended Learning untuk Pelatihan Vokasi. Bandung: PT. Srikandi Empat Widya Utama, 2020.

Nawawi, Hadari, Metode Penelitian Bidang Sosial, (Yogyakarta: Gajah Mada University Press, 1984)

Novalia, Lizna, A New Shape of Christian Education In Indonesian Contex: Suatu Upaya Mempersiapkan Sumber Daya Manusia yang Unggul di SETIA Jakarta, Jurnal Phronesis, vol. 2 No. 2 Desember 2019

Belo, Yosia, Pendidikan Agama Kristen dalam Matius 28:19-20- Jurnal Luxnos Vol. 5, No. 2, Edisi Juli-Desember 2019

Jarwati Saputra, Dewi Priskawati, Blended Learning: Solusi Pembelajaran New Normal Untuk Pendidikan Agama Kristen Di Era Revolusi Industri 4.0 dalam Jurnal Didaxei, Vol. 1 No. 22020

Sugiyono, Metode Penelitian Kombinasi (Bandung: Alfabeta, 2011)

https://tekno.kompas.com/read/2020/12/23/14250037/ini-daftar-10-youtuberterkaya-2020-versiforbes?page=all\#: :text=Jimmy\%20Donaldson\%20atau\%20yang\%20lebih,ga bungan\%20adegan\%20aksi\%20dan\%20humor.

https://mediaindonesia.com/humaniora/341711/deddy-corbuzier-youtuberterkaya-di-indonesia

https://money.kompas.com/read/2020/06/22/050300626/ini-10-youtuberindonesia-dengan-penghasilan-tertinggi-?page=all. 
https://www.liputan6.com/bisnis/read/4451875/terbaru-daftar-10-orang-terkayadi-dunia

https://www.simulasikredit.com/perusahaan-yang-mati-karena-disruptionteknologi-baru/

https://edukasi.sindonews.com/read/90540/144/banyak-lembaga-pendidikan-

gulung-tikar-pemerintah-diminta-turun-tangan-1593871642?showpage=all https://news.detik.com/berita/d-5183059/resmikan-universitas-siber-asia-wapresmaruf-dorong-e-learning

https://www.gurupendidikan.co.id/pengertian-inovasi/

https://www.yuswohady.com/2019/10/25/nadiem-dan-disrupsi-pendidikan-kita/ http://journal.ui.ac.id/index.php/jkmi/article/viewFile/9945/67546121 